ESPAÇO IMAGEM

IMAGing SPACE

Responsável: Manoel Barros Bértolo

\title{
Imagem Clínica de Púrpura de Henoch-Schönlein
}

\section{Clinical Imase in Henoch-Schönlein Purpura}

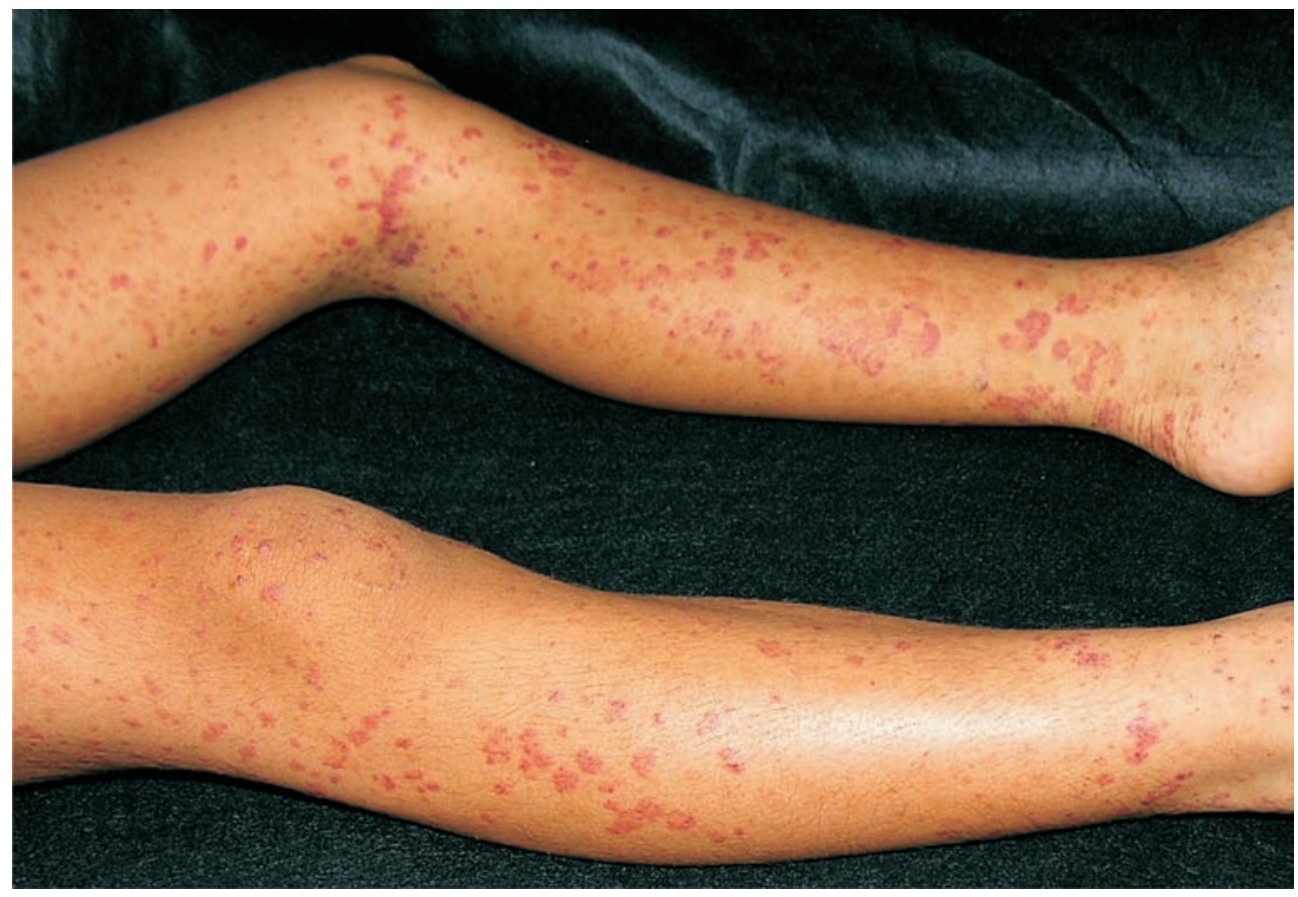

O paciente, masculino, 9 anos, branco, desenvolve clinicamente púrpura palpável em MMII, angina abdominal com dois episódios de sangramento intestinal e artrite de tornozelos. Avaliação laboratorial evidencia discreta anemia (hematócrito de 34\%), leucocitose de $16.400 / \mathrm{mm}^{3}$, plaquetas normais, VHS $36 \mathrm{~mm}$ na primeira hora, escórias azotadas normais e urina de 24 horas com 476 mg de proteína, exame de urina com hematúria microscópica.

Caso encaminhado por Luiz Sérgio Guedes-Barbosa, doutor em Reumatologia pela Universidade de São Paulo (USP), professor-associado do Hospital Universitáio Júlio Müller da Universidade Federal de Mato Grosso (UFMT). Av. Tenente Coronel Duarte, 2057, Cuiabá, MT-78015-501, e-mail: Isguedes@brturbo.com.br. 